\title{
Climate change impacts and adaptation assessment in Bangladesh
}

\author{
Anwar Ali* \\ Space Research and Remote Sensing Organization (SPARRSO), A gargaon, Sher-e-Bangla Nagar, Dhaka 1207, Bangladesh
}

\begin{abstract}
Bangladesh is likely to be one of the most vulnerable countries in the world to climate change. This paper discusses the possible impacts of climate change in Bangladesh through tropical cyclones, storm surges, coastal erosion and back water effect. The possible increase in cyclone frequency in the Bay of Bengal, lying south of Bangladesh, due to climate change is looked at by analyzing the cyclone data for $119 \mathrm{yr}$. Both qualitative and quantitative discussions are made on cyclone intensity increase for a sea surface temperature rise of 2 and $4^{\circ} \mathrm{C}$. Different scenarios of storm surges under different climate change conditions are developed by using a numerical model of storm surges for the Bay of Bengal. Possible loss of land through beach erosion due to sea level rise on the eastern coast of Bangladesh is examined. Some discussions are also made on the impacts of back water effect due to sea level rise on flood situations in the country. Finally, a few remarks are made on the adaptation options for Bangladesh in the event of climate change.
\end{abstract}

KEY WORDS: Bangladesh · Climate change - Impacts · Tropical cyclone - Storm surge · Erosion · Back water effect · Adaptations

\section{INTRODUCTION}

Bangladesh is a disaster-prone country. Almost every year, the country experiences disasters of one kind or another-such as tropical cyclones, storm surges, coastal erosion, floods, and droughts - causing heavy loss of life and property and jeopardizing the development activities. The country is already beset with many problems like high population density (120 million people living in an area of $144000 \mathrm{~km}^{2}$ ), shortage of land to accommodate the people, food security, human health, illiteracy, and so forth. The abovementioned types of disasters make the problems all the more complicated. In the foreseeable future, Bangladesh is likely to be one of the most vulnerable countries of the world in the event of climate change. The global warming due to the increase in greenhouse gas concentrations in the earth's atmosphere and the consequent sea level rise (SLR) are going to add fuel to the fire. Almost

*E-mail: sparrso@bangla.net every sector of socio-economic life in Bangladesh is likely to be affected by climate change.

A number of studies on the impact of climate change in Bangladesh exist. Notable among them are those of Mahtab (1989), Pramanik \& Ali (unpubl.), BCAS (1994), BUP (1994), and Bangladesh Climate Change Country Study Program (1997). Quite a few details have been discussed in these and other studies with respect to impacts, adaptation, awareness, and mitigation.

Most of the climate change impacts in Bangladesh are likely to come from the south - that is, the Bay of Bengal and the adjoining North Indian Ocean. These waters are the sources of tropical cyclones and storm surges, coastal erosion, monsoon wind, evaporation for monsoon rainfall, floods, and droughts. Considering these, the present paper concentrates on the following topics: tropical cyclones, storm surges, coastal erosion, and back water effect on floods in Bangladesh. The paper also discusses some possible adaptation procedures that may be undertaken in Bangladesh to face the challenge of climate change in the future. 


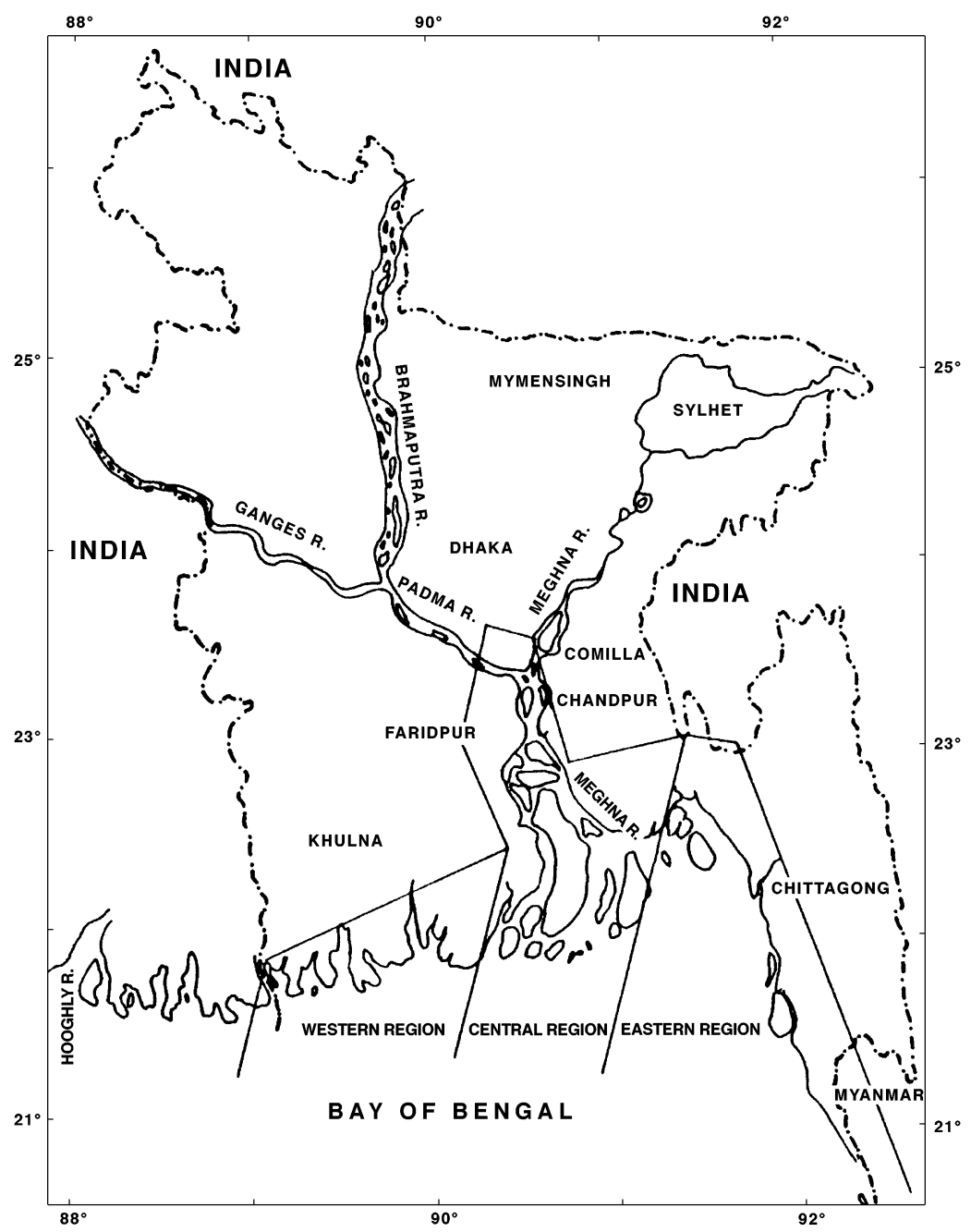

Fig. 1. Map of Bangladesh showing coastal area and the major river system

\section{COASTAL GEOMORPHOLOGY OF BAN G LADESH}

The geographical location and geomorphological conditions of Bangladesh have made the country one of the most vulnerable ones to climate change, particularly to SLR. To put the present discussions into perspective, a very brief description of the geomorphological conditions of Bangladesh, particularly of its coastal region, is given here.

Bangladesh is situated at the interface of 2 different environments, with the Bay of Bengal to the south and the Himalayas to the north. This peculiar geography of Bangladesh causes not only life-giving monsoons but also catastrophic ravages of natural disasters, to which now are added climate change and SLR.

The country has a very low and flat topography, except the northeast and southeast regions. A bout $10 \%$ of the country is hardly $1 \mathrm{~m}$ above the mean sea level (MSL), and one-third is under tidal excursions. The country has 3 distinct coastal regions-namely, western, central, and eastern coastal zones (Fig. 1).

The western part, also known as the Ganges tidal plain, comprises the semiactive delta and is criss-crossed by numerous channels and creeks. The topography is very low and flat. The southwestern part of the region is covered by the largest mangrove forest of the world, popularly known as Sundarbans, named after the 'Sundri' trees. The mangrove forests act as deterrents to the furiousness of tropical cyclones and storm surges. The central region is the most active one, and continuous processes of accretion and erosion are going on here. The very active M eghna River estuary lies in the region. The combined flow of 3 mighty rivers-the Ganges, the Brahmaputra, and the Meghna (commonly known as the GBM river system and ranking as one of the largest river systems in the world) - discharges under the name of M eghna into the northeastern corner of the Bay of Bengal. This estuarial region has seen the most disastrous effects of tropical cyclones and storm surges in the world and is very vulnerable to such calamities. The eastern region, being covered by hilly areas, is more stable, and it has one of the longest beaches in the world.

\section{TROPICAL CYCLONES}

About 80 tropical storms (tropical cyclones with wind speeds greater than or equal to $17 \mathrm{~m} \mathrm{~s}^{-1}$ ) form in the world's waters every year (McBride 1995). Of these, about $6.5 \%$ form in the North Indian Ocean (Bay of Bengal and Arabian Sea) (Neumann 1993). Since the frequency of cyclones in the Bay of Bengal is about 5 to 6 times the frequency in the Arabian Sea (IMD 1979), the Bay of Bengal share comes out to be about $5.5 \%$. The breakdown of this $5.5 \%$ for the littoral countries of the Bay of Bengal is given in the last row of Table 1. Bangladesh is hit by about $0.93 \%$ $(\sim 1 \%)$ of the world's total tropical storms, India by $3.34 \%$, Myanmar by $0.51 \%$, Sri Lanka by $0.22 \%$, and $0.50 \%$ die in the Bay without hitting any country. These numbers were arrived at by considering the 
Table 1. Number of cyclones forming in the Bay of Bengal and hitting the littoral countries (1877 to 1995). CS: cyclonic storm; SCS: severe cyclonic storm

\begin{tabular}{|lcccrrr|}
\hline Type & Bangladesh & India & Myanmar & Sri Lanka & Dead & Total \\
\hline All types & 154 & 848 & 71 & 35 & 115 & 1223 \\
Depressions & 68 & 539 & 24 & 15 & 69 & 715 \\
CS & 43 & 197 & 23 & 12 & 35 & 310 \\
SCS & 43 & 112 & 24 & 8 & 11 & 198 \\
CS+SCS & 86 & 309 & 47 & 20 & 46 & 508 \\
Percent of global total CS+SCS & 0.93 & 3.34 & 0.51 & 0.22 & 0.50 \\
\hline
\end{tabular}

tropical storms that formed in the Bay of Bengal during the period 1877 to 1995.

It would seem that Bangladesh is not a high-risk cyclone-prone area. The situation, however, is otherwise. If the world's tropical cyclones with death tolls in excess of 5000 are considered, it is found that 16 out of the 35 such disasters occurred in Bangladesh and 11 in India (Table 2). A bout 53\% of the world deaths from these cyclones took place in Bangladesh and about $23 \%$ in India, for a combined total of $76 \%$ in these 2 countries. Bangladesh and India suffer most, although both of them together are hit by only $4.27 \%$ of the world storms. It is to be noted that major cyclone disasters are still continuing in Bangladesh and India. Examples are the recent Bangladesh cyclones of 1985, 1988, and 1991 causing deaths of 11069,5708 , and 138000 , respectively. If global warming causes any increase in cyclone activity, the situation in Bangladesh and India is likely to further worsen.

\subsection{Would the cyclone frequency increase?}

One necessary but not sufficient condition for tropical cyclone formation is that the sea surface should have a minimum temperature of about 26 to $27^{\circ} \mathrm{C}$. This leads to the speculation that any rise in sea surface temperature (SST) due to climate change is likely to be accompanied by an increase in cyclone frequency. The role of SST in the genesis and intensification of tropical cyclones has been well demonstrated, for example, by Miller (1958), Wendland (1977), Gray (1979), Emanuel (1987, 1988), and Saunders \& Harris (1997). The highest number of tropical cyclones, about 33\% of the world total, form in the western North Pacific, which is a vast area of very warm waters, some about $30^{\circ} \mathrm{C}$ (Frank 1985). The area just west of Central America (in the Pacific) has the highest frequency of tropical cyclone genesis per unit area in the world; its average SST is about $29^{\circ} \mathrm{C}$. Positive correlations between the North Atlantic cyclone activity and SST immediately west of Africa have been established, as well as correlations between cyclone occurrence and SST in the waters around Australia (M cBride 1995). Using SST data for the Bay of Bengal for the period 1951 to 1987, J oseph (unpubl.) has shown that SST has been increasing since 1951. But an analysis by Ali (1995) and Ali \& Chowdhury (1997) of all kinds of tropical cyclones forming in the Bay of Bengal

Table 2. Deaths associated with noteworthy tropical cyclone disasters in the world. (Revised after Ali \& Chowdhury 1997)

\begin{tabular}{|c|c|c|}
\hline Year & Location & Deaths \\
\hline 1584 & Bangladesh & 200000 \\
\hline 1737 & India & 300000 \\
\hline 1779 & India & 20000 \\
\hline 1780 & Antilles & 20000 \\
\hline 1822 & Bangladesh & 40000 \\
\hline 1833 & India & 50000 \\
\hline 1839 & India & 20000 \\
\hline 1854 & India & 50000 \\
\hline 1864 & India & 50000 \\
\hline 1876 & Bangladesh & 100000 \\
\hline 1881 & China & 300000 \\
\hline 1895 & India & 5000 \\
\hline 1897 & Bangladesh & 175000 \\
\hline 1900 & Texas, USA & 6000 \\
\hline 1906 & Hong Kong & 10000 \\
\hline 1912 & Bangladesh & 40000 \\
\hline 1919 & Bangladesh & 40000 \\
\hline 1923 & Japan & 250000 \\
\hline 1937 & Hong Kong & 11000 \\
\hline 1941 & Bangladesh & 7500 \\
\hline 1942 & India & 40000 \\
\hline 1960 & Bangladesh & 5149 \\
\hline 1960 & Japan & 5000 \\
\hline 1961 & Bangladesh & 11468 \\
\hline 1963 & Bangladesh & 11520 \\
\hline 1963 & Cuba-Haiti & 7196 \\
\hline 1965 (11 M ay) & Bangladesh & 19279 \\
\hline 1965 (31 May) & Bangladesh & 12000 \\
\hline 1970 & Bangladesh & 500000 \\
\hline 1971 & India & 10000 \\
\hline 1977 & India & 10000 \\
\hline 1985 & Bangladesh & 11069 \\
\hline 1988 & Bangladesh & 5708 \\
\hline 1989 & India & 20000 \\
\hline 1991 & Bangladesh & 138000 \\
\hline
\end{tabular}


between 1877 and 1990, extended up to 1995 in this paper, shows no corresponding increase in cyclone frequency.

In the present discussions, cyclones have been categorized, as mostly usual, into 3 classes: depressions (wind speed less than $17 \mathrm{~m} \mathrm{~s}^{-1}$ ), cyclonic storms or tropical storms (CS, with wind speed between 17 and $24 \mathrm{~m}$ $\mathrm{s}^{-1}$ ), and severe cyclonic storms (SCS, with wind speed greater than $24 \mathrm{~m} \mathrm{~s}^{-1}$ ). No trend in depressions is observed. However, the CS and SCS combined show an oscillation of about $40 \mathrm{yr}$. The reasons for such an oscillatory behavior are not clear. The last highest peak occurred in about 1970, and since then the Bay of Bengal has experienced a decreasing trend in the number of storms.

Although no trend in storm frequency could be established in relation to the SST increase in the Bay of Bengal, we can look at the cyclone frequency and SST relation from a different angle, as discussed below.

It can be seen in Table 1 that about 115 cyclones (more than the total for Sri Lanka and Myanmar) died in the Bay of Bengal without hitting any country. There are another 250 or so recorded cyclones (IMD 1979) that are not included in the table (the table contains only those cyclones that have well defined tracks). These 250 cyclones were either stationary or short lived (less than a day) or had no well-defined tracks. If there were higher SSTs, these 365-plus cyclones $(250+115)$ could have further developed and, by striking the littoral countries, increased the frequency of cyclones making landfall and thereby causing more casualties and damage. In this sense at least, it may be said that an increase in SST could have energized the weaker (dead) cyclones and the not-taken-into-account short-lived cyclones, making them more persistent and thus increasing the number of cyclones hitting a country. Thus it may be crudely said that any future SST rise may very likely be accompanied by an increase in country-frequency of the cyclones in the Bay of Bengal area.

\subsection{Cyclone intensity}

It is almost certain that an increase in SST will be accompanied by a corresponding increase in cyclone intensity (wind speed). The relationship between cyclone intensity and SST is well discussed in the literature. Recently, Emanuel (1987) has developed a relationship between maximum sustained wind speed and SST. If the IPCC standard of a lower bound of $2^{\circ} \mathrm{C}$ and an upper bound of $4^{\circ} \mathrm{C}$ rise in temperature by 2010 is used, the corresponding increase in maximum cyclone wind speed using Emanuel's table comes out to be 10 and $22 \%$, respectively, relative to the threshold temperature of $27^{\circ} \mathrm{C}$ (Ali 1996). It may, however, be pointed out here that the cyclone intensification as mentioned above is not certified by observations and numerical experiments. Nevertheless, it indicates that a good number of depressions will become cyclonic storms, that cyclonic storms will become severe cyclonic storms, and that severe cyclonic storms will become even more severe. As a consequence, the disastrous consequence of cyclones will increase manifold.

\section{STORM SURGES}

Storm surges are generated by the winds and the atmospheric pressure changes associated with cyclones. Wind is the main contributing factor $(-90 \%)$. It exerts stress on the water underneath, and surge is generated. In Bangladesh, storm surge heights in excess of $10 \mathrm{~m}$ are not uncommon. A few examples of storm surge heights are given in Table 3 in the column under 'business as usual' - meaning normal conditions (that is, no climate change). Only those cyclones are included in which there was a death toll of at least 1000.

There are a number of reasons for the storm surge amplifications on the Bangladesh coast. These have been discussed, for example, by Ali (1980) and Ali \& Chowdhury (1997). Shallow water in the north Bay, the northward-converging nature of the Bay (at the head of which Bangladesh is situated), and high astronomical tides are the main causes of storm surge amplifications on the Bangladesh coast. As mentioned earlier, the M eghna estuarial region is the area where most of the surge amplifications occur. The country's low and flat terrain is easily flooded by amplified surge waters, thus converting the coastal land area into a vast sea.

Any increase in SST is likely to cause greater convective instability, leading to an increase in the wind speed. The stress exerted by wind on water underneath is proportional to the square of the wind velocity. Thus an increase in SST due to climate change will lead to higher storm surges and a higher risk of coastal disasters in low-lying coastal areas of Bangladesh. Using a numerical storm surge model for the north Bay of Bengal, Ali (1996) developed a few storm surge scenarios under 2 different temperature increases $(2$ and $4^{\circ} \mathrm{C}$ rise) and 2 SLRs ( 0.3 and $1.0 \mathrm{~m}$ rise). The April 1991 cyclone that hit Bangladesh, killing about 138000 people, was taken as a model case. The maximum wind speed of the cyclone was $225 \mathrm{~km} \mathrm{~h}^{-1}$. Using Emanuel's relation to obtain a 10 and $22 \%$ rise in wind speed due to a rise in temperature of 2 and $4^{\circ} \mathrm{C}$, respectively, the corresponding wind speed comes out to be $248 \mathrm{~km} \mathrm{~h}^{-1}$ (for a $2^{\circ} \mathrm{C}$ rise in SST) and $275 \mathrm{~km} \mathrm{~h}^{-1}$ 
Table 3. Storm surge scenarios for cyclones affecting Bangladesh since 1960, each of which caused at least 1000 human deaths. Business as usual: no climate change; 2 and $4^{\circ} \mathrm{C}$ : lower and upper bounds of the rise in temperature by 2010 , as given by the IPCC

\begin{tabular}{|lrccc|}
\hline Cyclone date & Deaths & \multicolumn{2}{c|}{ Storm surge height $(\mathrm{m})$} \\
& & Business as usual & $2^{\circ} \mathrm{C}$ & $4^{\circ} \mathrm{C}$ \\
\hline Oct 9, 1960 & 3000 & 3.05 & 3.69 & 4.55 \\
Oct 30, 1960 & 5149 & $4.57-6.10$ & $5.53-7.38$ & $6.80-11.00$ \\
May 9, 1961 & 11468 & $2.44-3.05$ & $2.95-3.69$ & $3.64-4.55$ \\
May 28, 1963 & 11520 & $4.27-5.18$ & $5.17-6.27$ & $6.36-7.72$ \\
May 11, 1965 & 19279 & 3.66 & 4.43 & 5.45 \\
May 31, 1965 & 12000 & $6.10-7.62$ & $5.53-9.22$ & $11.00-11.35$ \\
Nov 12, 1970 & 500000 & $6.10-9.14$ & $5.53-11.06$ & $11.00-13.62$ \\
May 25, 1985 & 11069 & $3.05-4.57$ & $3.69-5.53$ & $4.55-6.80$ \\
Nov 29, 1988 & 5708 & $1.52-3.05$ & $1.84-3.69$ & $2.27-4.55$ \\
Apr 29, 1991 & 138000 & $6.10-7.62$ & $5.53-9.22$ & $11.00-11.35$ \\
\hline
\end{tabular}

(for a $4^{\circ} \mathrm{C}$ rise in temperature). The results of the model calculation for a grid point corresponding to a place near Chittagong are given in Table 4. Chittagong is the largest seaport in Bangladesh and is situated in the area where most of the highest storm surges occur. It can be seen that storm surge heights increase with an increase in wind speed and SST. On the other hand, SLR tends to reduce the surge heights if wind speed remains constant. It is to be noted here that the model had a fixed boundary and as a result could not simulate the surge height for a moving shoreline. SLR will convert the hitherto land area into a part of the sea which will then become a shallow water area where the surge will be amplified. Thus, although the SLR will apparently reduce the surge height in the present sea water, it will increase the surge height in the newly converted (from land to sea) sea area.

The maximum surge height for the April 1991 cyclone, as calculated by the model, came out to be about $7.6 \mathrm{~m}$, which agrees reasonably well with observation. This is used as the basis for calculating the percentage increases that are given within parentheses. With no SLR, surge height increases by about 21 and $49 \%$ for an SST rise of 2 and $4^{\circ} \mathrm{C}$, respectively. Using these per-

Table 4. Storm surge heights $(\mathrm{m})$ under different sea surface temperature and sea level rise scenarios (wind speed of $225 \mathrm{~km} \mathrm{~h}^{-1}$ corresponds to that of the April 1991 cyclone). (Taken from Ali 1996)

\begin{tabular}{|lccc|}
\hline & $\begin{array}{c}\text { Current temp. } \\
\left(27^{\circ} \mathrm{C}\right)\end{array}$ & $\begin{array}{c}2^{\circ} \mathrm{C} \\
\text { increase }\end{array}$ & $\begin{array}{c}4^{\circ} \mathrm{C} \\
\text { increase }\end{array}$ \\
\hline $\begin{array}{l}\text { Wind speed }\left(\mathrm{km} \mathrm{h}^{-1}\right) \\
\text { Surge height in m }\end{array}$ & 225 & 248 & 275 \\
$\begin{array}{l}\text { (\% change) } \\
\text { Sea level rise }=0.0 \mathrm{~m}\end{array}$ & $7.6(0)$ & $9.2(21)$ & $11.3(49)$ \\
Sea level rise $=0.3 \mathrm{~m}$ & $7.4(-3)$ & $9.1(20)$ & $11.1(46)$ \\
Sea level rise $=1.0 \mathrm{~m}$ & $7.1(-7)$ & $8.6(13)$ & $10.6(40)$ \\
\hline
\end{tabular}

centages, the possible storm surge heights for the cyclones that have hit Bangladesh since 1960 have been calculated, and they are given in Table 3.

It is well known that storm surge generation and its amplification depend on a number of factors. The surge scenarios given above are based on a simple prediction model that considers only the increase in wind speed, and as such it has some limitations.

Surge water that hits the coastline of Bangladesh travels far inland. On the basis of the penetration distance of surge water and the depth of inundation, MCSP (1992) has delineated the coastal area of Bangladesh into a Risk Zone (RZ) and a High Risk A rea (HRA). RZ is defined as the area where there is a risk that damage to property may occur because of inundation by surge water. The HRA within the RZ refers to areas where there is a possibility of loss of lives due to substantial inundation by storm surges. The areas have been delineated by taking into consideration a number of factors, such as observed surge heights and penetration distance, topography and field survey, and so forth. Obviously, any increase in surge heights due to climate change will lead to an increase in the extent of the RZ and HRA. This may upset implementation of the management plan that has been undertaken on the basis of the MCSP (1992) delineation, such as construction of cyclone shelters.

\section{COASTAL EROSION}

Erosion in the coastal area of Bangladesh is another big point of concern for Bangladesh. Heavy discharge currents through the GBM river system, wave action due to strong southwest monsoon winds, high astronomical tides, and storm surges in the Bay of Bengal are the main causes of erosion (and accretion) in the coastal area of Bangladesh. Superimposed on these 
causes, SLR has a long-term effect on coastal erosion in the country.

Erosion and accretion activities in Bangladesh have been studied by a number of authors. Some reviews of these works are available in Pramanik (1983), Ali (unpubl.), MCSP (1992), and Islam et al. (1999). Erosion due to SLR has been discussed, for example, by Ali \& A hmad (unpubl.) and Islam et al. (1999). The latest study (Islam et al. 1999) was done under the U.S. Country Studies Program, and some of the salient features of the study are presented here. The study is based on the erosion formula given by Bruun (1962). For the development of the equation, reference is made to Bruun (1962). The equation is as follows:

$$
x=a b /(e+d)
$$

where $x$ is the shoreline recession due to SLR, $a$ is the rise in water level due to SLR, e is the elevation of the shore, and $d$ is the depth of water at a distance $b$ from the coastline.

The formula was applied to the eastern region of Bangladesh (Fig. 1). The area was selected by considering the better applicability of Bruun's law there. The study area is bounded by latitudes $20^{\circ} 40^{\prime} \mathrm{N}$ and $22^{\circ} 13.5^{\prime} \mathrm{N}$ and longitudes $91^{\circ} 45^{\prime} \mathrm{E}$ and $92^{\circ} 2^{\prime} \mathrm{E}$. The values of the parameters were measured by conducting a field survey at 21 different locations along the coast with profiles being perpendicular to the coastline. Each point was georeferenced with a global positioning system (GPS).

Not all of the 21 locations have sandy shores, which is a prerequisite for application of Bruun's formula. Only 7 points were found suitable. The recession distances were calculated for these points under 3 values of SLR $-0.30,0.75$, and $1.00 \mathrm{~m}$. For $0.30 \mathrm{~m}$ SLR, the recession varies from 0.18 to $0.39 \mathrm{~m} \mathrm{~cm}^{-1}$ (meaning that the shoreline will recede 0.18 to $0.39 \mathrm{~m}$ per $1 \mathrm{~cm}$ rise in SLR); for $0.75 \mathrm{~m}$, the range is 0.41 to $0.91 \mathrm{~m}$ $\mathrm{cm}^{-1}$; and for $1.00 \mathrm{~m}, 0.58$ to $1.30 \mathrm{~m} \mathrm{~cm}^{-1}$. On average, a recession of $0.87 \mathrm{~m}$ occurs per $1 \mathrm{~cm}$ rise in sea level. That is, recession distance through erosion due to SLR is about 87 times the SLR. The results agree reasonably well with others-for example, 100 times for the Florida coast (Bruun 1962) and 60 to 80 times for the Belgium-to-Denmark coast (Hekstra 1989). It is to be mentioned here that for the same beach generally the ratio $b /(e+d)$ is nearly a constant. But in the present case, this is not so because of the peculiar geomorphological characteristics of the Bangladesh coast.

The loss of land area under 0.30 and $0.75 \mathrm{~m}$ SLRs was also calculated. The result comes out to be 5.80 and $11.20 \mathrm{~km}^{2}$, respectively. A bout $95 \%$ of the area is agricultural land. In that sense, loss in food grain production with respect to the present will be about 13750 and 252000 metric tonnes, respectively.

\section{BACK WATER EFFECT}

Back water effect (BWE) generally refers to the retardation of a river outflow by a rise in the level of water at the mouth of the river. The effect may be from a main river to a tributary or from sea to a river. M ostly it is an estuarial phenomenon. Not only do conditions at the mouth of the river retard the outflow, but often a flow reversal occurs-that is, water may flow from the sea to a river.

BWE is very pronounced in Bangladesh, particularly in the Meghna River estuary, through which about $90 \%$ of the river water in the country discharges into the Bay of Bengal. It is particularly important during flood seasons. As a consequence, floodwater inside the country continues to accumulate, bringing more areas under inundation and increasing the length and depth of inundation in areas already inundated, thus further aggravating the flood situation that already exists.

BWE in Bangladesh arises as a result of a number of dynamic conditions/causes in the Bay of Bengal. The principal ones are (1) southwest monsoon wind during the rainy season, (2) astronomical tides, and (3) storm surges. The phenomenon of BWE under these conditions has been discussed by using numerical models, for example, by Ali (1995) and Ali et al. (1997a,b). A nother non-dynamic and long-term BWE is likely to be caused by the SLR, which will raise the level of water at the mouth (estuary) of a river. As an example, consider the Meghna River, which discharges at the northeastern corner of the Bay of Bengal. Average discharge through this river during flood peaks is of the order of $1.9 \times 10^{5} \mathrm{~m}^{3} \mathrm{~s}^{-1}$. The present slope of the M eghna River from about $100 \mathrm{~km}$ inland near Chandpur, a river port (see Fig. 1), to its mouth is about 1.136 $\mathrm{cm} \mathrm{km}^{-1}$. If the sea level rises by $1.0 \mathrm{~m}$, the resultant river slope will become $0.136 \mathrm{~cm} \mathrm{~km}^{-1}$. Similar situations are likely to occur all along the coastal area of Bangladesh, thus making the flood situation even worse.

\section{ADAPTATION}

Although Bangladesh is an insignificant or virtually zero contributor to the greenhouse gas emissions that affect global climate change, it is ironic that it has to suffer so disastrously from the effects of climate change that are likely to occur in the coming decades. It must, therefore, adapt itself to the changing circumstances. Adaptation requires assessment of vulnerability from the viewpoint of different disciplines, which then requires an integrated approach. Discussed below are some adaptation strategies for the coastal area that may be pursued in Bangladesh. 
We have 3 adaptive options: retreat, accommodation and protection. Considering the high population density, future population projections, and shortage of land, retreat is not possible. We should pursue the 2 other options. We should also strive to get land from the sea.

As discussed in MCSP (1992) and by Ali (1996), the intrusion distance of surge water inside Bangladesh is heavily dependent on resistance at the land surface. One of the important sources of such resistance is the forest. As mentioned earlier, in the western coastal area of Bangladesh lies a large mangrove forest. Although that area is almost flat, damage due to storm surges there is still much less than it is in other areas that have less mangrove coverage. Thus one of the most immediate and useful adaptation strategies should be to protect the mangrove forest from denudation and implement a massive afforestation program all along the coastal belt. In fact, Bangladesh has a couple of ongoing projects aiming at that. Afforestation will also help stabilize the land, create more accretion leading to more land, and also raise the level of topography that will reduce inundation by SLR.

Cropping practices may also be changed in the coastal area. New rice varieties may be developed to withstand higher salinity and higher temperatures and be grown and harvested during the non-cyclonic period.

Bangladesh has undertaken a massive program of constructing cyclone shelters in the coastal area. These specially built shelters will be used as shelters for human beings, animals, and property during cyclonic periods and as community centers, schools, and so forth during normal times. The number of shelters necessary has been calculated on the basis of storm surge heights at the coast and the inland intrusion of surge water. The situation may change under the future temperature increase and SLR, and in that case the requisite number of shelters may have to be revised by considering the various scenarios and actions taken accordingly.

Construction of embankments in the coastal area is another adaptation and protection measure. Embankments will obstruct the penetration of surge water; and even if the surge overtops them, the water energy will then be greatly reduced.

One of the best ways to adapt to climate change is to involve people at the grass-root level. The people of Bangladesh are very enterprising and innovative. They have been living with disasters for a long, long time. Adapting to changing situations is a familiar traditional practice in Bangladesh. What is important is to carry out detailed scientific studies, to make the people aware of the impending dangers, and to develop, along with them, methods of adaptation.

\section{CONCLUSIONS}

This paper has discussed the vulnerability of Bangladesh to climate change with particular reference to tropical cyclone frequency and intensity, storm surges, coastal erosion, and back water effect. The analysis has been both qualitative and quantitative. The vulnerability assessments may have many shortcomings in terms of analytical procedures, and more research is needed to arrive at a more reliable assessment so that a better response mechanism can be developed. A few adaptation options have also been identified. These options will pay a favorable return even if the climate change does not occur.

Acknowledgements. The author expresses his gratitude to the Chairman, SPARRSO, for kindly giving him the permission to publish the paper and to the referees for their valuable comments.

\section{LITERATURE CITED}

Ali A (1980) Storm surges in the Bay of Bengal and their numerical modelling. SARC Tech Rep no. 120/80, Bangladesh Atomic Energy Commission, Dhaka

Ali A (1995) Numerical investigation into the retardation of flood water outflow through the Meghna river in Bangladesh due to SW monsoon wind. Estuar Coast Shelf Sci 41:689-704

Ali A (1996) Vulnerability of Bangladesh to climate change and sea level rise through tropical cyclones and storm surges. J Water Air Soil Pollut 92d:171-179

Ali A, Chowdhury J U (1997) Tropical cyclone risk assessment with special reference to Bangladesh. MAUSAM (formerly Indian J Meteorol Hydrol Geophys) 48:305-322

Ali A, Rahman H, Chowdhury SSH, Begum QN (1997a) Back water effect of tides and storm surges on fresh water discharge through the Meghna estuary. J Remote Sensing Environ 1:85-95

Ali A, Rahman H, Chowdhury SSH (1997b) River discharge, storm surges and tidal interactions in the Meghna river mouth in Bangladesh. MAUSAM (formerly Indian J Meteorol Hydrol Geophys) 48:531-540

Bangladesh Climate Change Country Study Program (1997) Assessment of vulnerability and adaptation to climate change. Final report, Department of Environment, Govt of Bangladesh

BCAS (1994) Vulnerability of Bangladesh to climate change and sea level rise: concepts and tools for calculating risk in integrated coastal zone management, Vols $1 \& 2$. Technical Report, Bangladesh Center for Advanced Studies, Dhaka

Bruun P (1962) Sea level rise as a cause of shore erosion. J Waterways Harbors Div Proc Am Soc Civ Eng 88: 117-130

BUP (1994) Bangladesh: greenhouse effect and climate change. Briefing documents, Nos. 1-7, Bangladesh Unnayan Parishad (BUP), Dhaka, Bangladesh; Center for Environmental and Resource Studies (CEARS), University of Waikato, Hamilton; and Climate Research Institute, University of East Anglia, Norwich

Emanuel KA (1987) The dependence of hurricane intensity. Nature 329:483-485 
Emanuel KA (1988) Toward a general theory of hurricanes. Am Sci 76:371-379

Frank WM (1985) Tropical cyclone formation. In: Elsberry RL (ed) Global view of tropical cyclones, based on the International Workshop on Tropical Cyclones, November 25-December 5, Bangkok, Thailand. US Office of Naval Research M arine M eteorological Program, p 53-90

Gray WM (1979) Hurricanes: their formation, structure and likely role in the tropical circulation. In: Shaw DB (ed) Meteorology over tropical oceans. Royal Meteorological Society, Bracknell, p 155-218

Hekstra GP (1989) Global warming and rising sea levels: the policy implications. The Ecologist 19:4-15

IMD (1979) Tracks of storms and depressions in the Bay of Bengal and the A rabian sea 1877-1970. India M eteorological Department (IMD), New Delhi

Islam SMR, Huq S, Ali A (1999) Beach erosion in the eastern coastline of Bangladesh. In: Huq S, Karim Z, Asaduzzaman M, Mahtab F (eds) Vulnerability and adaption to climate change for Bangladesh. Kluwer Academic Publishers, Dordrecht, p 71-92
M ahtab F (1989) Effect of climate change and sea level rise on Bangladesh. Expert Group on climate change and sea level rise, Commonwealth Secretariat, London

M cBride J L (1995) Tropical cyclone formation. In: Elsberry RL (ed) Global perspectives on tropical cyclone. WMO Tech Doc WMO/TD-No. 693, Report No. TCP-38, WMO, Geneva, p 63-105 (reprinted 1996)

MCSP (1992) Multipurpose cyclone shelter program. Final Report. Vol XI Special Studies, UNDP/World Bank/Govt of Bangladesh Project No. BGD/91/025

Miller $\mathrm{BI}$ (1958) On the maximum intensity of hurricanes. J Meteorol 15:184-195

Neumann CJ (1993) Global overview. Chapter 1, Global guide to tropical cyclone forecasting. WMO, Geneva

Pramanik MAH (1983) Remote sensing applications to coastal morphological investigations in Bangladesh. PhD thesis, J ahangirnagar University, Savar, Dhaka

Saunders MA, Harris AR (1997) Statistical evidence links exceptional 1995 Atlantic hurricane season to record sea warming. Geophys Res Lett 24:1255-1258

Wendland WM (1977) Tropical storm frequencies related to sea surface temperatures. J Appl Meteorol 6:477-481 